\title{
Genetic Diversity and Pathogenic Variation of Common Blight Bacteria (Xanthomonas campestris pv. phaseoli and X. campestris pv. phaseoli var. fuscans) Suggests Pathogen Coevolution with the Common Bean
}

\author{
Alexander B. C. Mkandawire, Robert B. Mabagala, Pablo Guzmán, Paul Gepts, and Robert L. Gilbertson
}

First author: Bunda College of Agriculture, P.O. Box 219, Lilongwe, Malawi and Department of Plant Pathology, University of California, Davis 95616; second author: Sokoine University of Agriculture, P.O. Box 3005 Subpost Office, Chuo Kikuu, Morogoro, Tanzania; third and fifth authors: Department of Plant Pathology, University of California, Davis 95616; fourth author: Department of Agronomy and Range Science, University of California, Davis 95616.

Current address of P. Guzmán: California Crop Improvement Association, University of California, Davis 95616.

Accepted for publication 8 February 2004.

\begin{abstract}
Mkandawire, A. B. C., Mabagala, R. B., Guzmán, P., Gepts, P., and Gilbertson, R. L. 2004. Genetic diversity and pathogenic variation of common blight bacteria (Xanthomonas campestris pv. phaseoli and X. campestris pv. phaseoli var. fuscans) suggests pathogen coevolution with the common bean. Phytopathology 94:593-603.

Common bacterial blight (CBB), caused by Xanthomonas campestris pv. phaseoli and X. campestris pv. phaseoli var. fuscans, is one of the most important diseases of common bean (Phaseolus vulgaris) in East Africa and other bean-growing regions. Xanthomonad-like bacteria associated with $\mathrm{CBB}$ in Malawi and Tanzania, East Africa, and in Wisconsin, U.S., were characterized based on brown pigment production, pathogenicity on common bean, detection with an X. campestris pv. phaseoli- or X. campestris pv. phaseoli var. fuscans-specific PCR primer pair, and repetitive element polymerase chain reaction (rep-PCR) and restriction fragment length polymorphism (RFLP) analyses. The common bean gene pool (Andean or Middle American) from which each strain was isolated also was determined. In Malawi, X. campestris pv. phaseoli and $X$. campestris pv. phaseoli var. fuscans were isolated predominantly from Andean or Middle American beans, respectively. In Tanzania, X. campestris pv. phaseoli var. fuscans was most commonly isolated, irrespective of gene pool; whereas, in Wisconsin, only X. campestris pv. phaseoli was isolated from Andean red kidney beans. Three rep-PCR fingerprints were

obtained for $X$. campestris pv. phaseoli strains; two were unique to East African strains, whereas the other was associated with strains collected from all other (mostly New World) locations. RFLP analyses with repetitive DNA probes revealed the same genetic diversity among $X$. campestris pv. phaseoli strains as did rep-PCR. These probes hybridized with only one or two fragments in the East African strains, but with multiple fragments in the other $X$. campestris pv. phaseoli strains. East African $X$. campestris pv. phaseoli strains were highly pathogenic on Andean beans, but were significantly less pathogenic on Middle American beans. In contrast, $X$. campestris pv. phaseoli strains from New World locations were highly pathogenic on beans of both gene pools. Together, these results indicate the existence of genetically and geographically distinct $X$. campestris pv. phaseoli genotypes. The rep-PCR fingerprints of $X$. campestris pv. phaseoli var. fuscans strains from East African and New World locations were indistinguishable, and were readily distinguished from those of X. campestris pv. phaseoli strains. Genetic diversity among $X$. campestris pv. phaseoli var. fuscans strains was revealed by RFLP analyses. East African and New World X. campestris pv. phaseoli var. fuscans strains were highly pathogenic on Andean and Middle American beans. Breeding for CBB resistance in East African beans should utilize $X$. campestris pv. phaseoli var. fuscans and New World X. campestris pv. phaseoli strains in order to identify germ plasm with the highest levels of resistance.
\end{abstract}

Common bean (Phaseolus vulgaris L.) is a major food crop that provides an inexpensive source of protein for both rural and urban households in East Africa. However, production of the crop is limited by numerous biotic and abiotic constraints. Common bacterial blight (CBB), caused by Xanthomonas campestris pv. phaseoli and X. campestris pv. phaseoli var. fuscans, is a widespread and destructive disease of common bean in Africa and other bean-growing regions $(1,22,24)$. Common blight bacteria survive between bean crops in association with seed, bean debris, and weeds $(10,13,26,32,33)$. Thus, effective CBB disease management involves the use of certified seed, crop rotation, and sanitation (e.g., deep plowing or removal of debris and weed management). In East Africa, most farmers do not have access to certified seed; and sanitation, weed management, and rotation options are limited (22). Thus, the development of cultivars with durable $\mathrm{CBB}$ resistance offers the most promising long-term and eco-

Corresponding author: R. L. Gilbertson; E-mail address: rlgilbertson@ucdavis.edu

Publication no. P-2004-0419-01R

(c) 2004 The American Phytopathological Society nomical means of disease management. To identify germ plasm that will be highly resistant to $\mathrm{CBB}$ and to facilitate disease resistance breeding for a given region, there is a need to identify the predominant common blight bacteria.

There is evidence of genetic diversity among common blight bacteria, although the significance of this diversity is not well understood. $X$. campestris pv. phaseoli var. fuscans can be differentiated from $X$. campestris pv. phaseoli strains based on phenotypic (i.e., X. campestris pv. phaseoli var. fuscans strains produce a brown melanin-like pigment in culture [14]) and genetic characteristics $(5,6,12,16,20)$. X campestris pv. phaseoli var. fuscans and $X$. campestris pv. phaseoli have been differentiated based upon restriction fragment length polymorphism (RFLP) analyses $(6,12,20)$, a random amplified polymorphic DNA fragment (5), DNA-DNA hybridization (16), and pulse field gel electrophoresis (6). rDNA sequence analysis revealed that strains of $X$. campestris pv. phaseoli and $X$. campestris pv. phaseoli var. fuscans were genetically distinct, but were more closely related to each other than to other $X$. campestris pathovars (4). Variability in the pathogenicity of $X$. campestris pv. phaseoli and $X$. campestris pv. phaseoli var. fuscans strains also has been reported $(27,37,45)$; 
however, distinct races of common blight bacteria, based on differential pathogenicity on defined $P$. vulgaris cultivars, have not been identified (10). This is consistent with the fact that CBB resistance is a quantitative trait $(10,32,42)$. X. campestris pv. phaseoli strains have been differentiated into pathogenic races based on reactions on tepary bean (P. acutifolius) lines $(27,49)$, but the significance of this variability in terms of common bean remains to be established.

More recently, DNA fingerprints, generated with the polymerase chain reaction (PCR), have been used to identify genetic diversity among strains of closely related bacteria $(21,30)$. In particular, the repetitive element PCR (rep-PCR) technique has been widely used. This method involves the use of primers based on highly conserved sequences dispersed throughout the bacterial genome and PCR to amplify DNA lying between these elements (47). The rep-PCR method has been used to identify and differentiate many plant-pathogenic bacteria, including pathovars of Pseudomonas syringae $(19,21,38,48)$ and $X$. campestris $(4,21,31$, $34,44,46)$.
The objectives of this study were to (i) characterize xanthomonad-like bacteria associated with CBB in bean-growing areas of Malawi and Tanzania in East Africa and in Wisconsin, (ii) assess the genetic diversity among these strains, and (iii) determine whether any relationship exists between genetic diversity among $X$. campestris pv. phaseoli and X. campestris pv. phaseoli var. fuscans strains and pathogenicity on beans of the Andean and Middle American gene pools. The results of this study are discussed in terms of the development of CBB-resistant common bean cultivars for East Africa.

\section{MATERIALS AND METHODS}

Bacterial strains and their identification. Bacterial strains used in this study are listed in Table 1 . These strains were recovered from bean leaves or seed collected during surveys conducted in East Africa (Malawi and Tanzania) and Wisconsin. In these surveys, representative bean fields in these regions were randomly selected and surveyed for CBB symptoms by examining

TABLE 1. Xanthomonad-like strains isolated from common bacterial blight samples collected during surveys of East Africa and Wisconsin

\begin{tabular}{|c|c|c|c|c|}
\hline Designation & Identity $^{w}$ & Geographic origin $^{\mathrm{x}}$ & Common bean gene pool source ${ }^{y}$ & Pathogenicity ${ }^{z}$ \\
\hline M11 & X. campestris pv. phaseoli & Bunda, Malawi & A & + \\
\hline $\mathrm{M} 12 \mathrm{~F}$ & X. campestris pv. phaseoli var. fuscans & Bunda, Malawi & A & + \\
\hline M13F & $X$. campestris pv. phaseoli var. fuscans & Bunda, Malawi & M & + \\
\hline $\mathrm{M} 14 \mathrm{~F}$ & $X$. campestris pv. phaseoli var. fuscans & Bunda, Malawi & M & + \\
\hline M15 & Xanthomonas spp. & Bunda, Malawi & A & - \\
\hline M16F & $X$. campestris pv. phaseoli var. fuscans & Bunda, Malawi & M & + \\
\hline M17 & X. campestris pv. phaseoli & Bunda, Malawi & A & + \\
\hline M18 & X. campestris pv. phaseoli & Rumphi, Malawi & $\ldots$ & + \\
\hline M19 & X. campestris pv. phaseoli & Rumphi, Malawi & A & + \\
\hline M20 & X. campestris pv. phaseoli & Rumphi, Malawi & A & + \\
\hline M27F & $X$. campestris pv. phaseoli var. fuscans & Rumphi, Malawi & M & + \\
\hline $\mathrm{M} 32 \mathrm{~F}$ & X. campestris pv. phaseoli var. fuscans & Rumphi, Malawi & M & + \\
\hline M33 & Xanthomonas spp. & Rumphi, Malawi & A & - \\
\hline $\mathrm{M} 23 \mathrm{~F}$ & X. campestris pv. phaseoli var. fuscans & Dedza, Malawi & M & + \\
\hline M24 & $X$. campestris pv. phaseoli & Dedza, Malawi & A & + \\
\hline M25 & $X$. campestris pv. phaseoli & Mzimba, Malawi & A & + \\
\hline M29 & X. campestris pv. phaseoli & Mzimba, Malawi & A & + \\
\hline $\mathrm{M} 31 \mathrm{~F}$ & X. campestris pv. phaseoli var. fuscans & Mzimba, Malawi & $\ldots$ & + \\
\hline $\mathrm{M} 26 \mathrm{~F}$ & X. campestris pv. phaseoli var. fuscans & Kasungu, Malawi & A & + \\
\hline M30 & X. campestris pv. phaseoli & Kasungu, Malawi & M & + \\
\hline M28 & Xanthomonas spp. & Kasungu, Malawi & A & - \\
\hline $\mathrm{T} 21 \mathrm{~F}$ & X. campestris pv. phaseoli var. fuscans & Iringa, Tanzania & $\ldots$ & + \\
\hline $\mathrm{T} 22 \mathrm{~F}$ & X. campestris pv. phaseoli var. fuscans & Iringa, Tanzania & M & + \\
\hline $\mathrm{T} 3 \mathrm{~F}$ & X. campestris pv. phaseoli var. fuscans & Iringa, Tanzania & A & + \\
\hline $\mathrm{T} 14$ & $X$. campestris pv. phaseoli & Iringa, Tanzania & A & + \\
\hline $\mathrm{T} 17 \mathrm{~F}$ & X. campestris pv. phaseoli var. fuscans & Iringa, Tanzania & A & + \\
\hline $\mathrm{T} 19 \mathrm{~F}$ & X. campestris pv. phaseoli var. fuscans & Iringa, Tanzania & A & + \\
\hline $\mathrm{T} 20 \mathrm{~F}$ & $X$. campestris pv. phaseoli var. fuscans & Iringa, Tanzania & A & + \\
\hline $\mathrm{T} 21$ & $X$. campestris pv. phaseoli & Iringa, Tanzania & A & + \\
\hline $\mathrm{T} 23 \mathrm{~F}$ & X. campestris pv. phaseoli var. fuscans & Iringa, Tanzania & A & + \\
\hline $\mathrm{T} 32 \mathrm{~F}$ & X. campestris pv. phaseoli var. fuscans & Iringa, Tanzania & A & + \\
\hline $\mathrm{T} 3-3$ & Xanthomonas spp. & Morogoro, Tanzania & A & - \\
\hline $\mathrm{T} 3-4$ & Xanthomonas spp. & Morogoro, Tanzania & A & - \\
\hline T5-1 & Xanthomonas spp. & Lushoto, Tanzania & M & - \\
\hline $\mathrm{T} 7-8 \mathrm{~F}$ & X. campestris pv. phaseoli var. fuscans & Lushoto, Tanzania & A & + \\
\hline $\mathrm{T} 7-9 \mathrm{~F}$ & X. campestris pv. phaseoli var. fuscans & Lushoto, Tanzania & M & + \\
\hline $\mathrm{T} 7-10 \mathrm{~F}$ & X. campestris pv. phaseoli var. fuscans & Lushoto, Tanzania & M & + \\
\hline T7-11 & Xanthomonas spp. & Lushoto, Tanzania & M & - \\
\hline $\mathrm{T} 7-12 \mathrm{~F}$ & X. campestris pv. phaseoli var. fuscans & Lushoto, Tanzania & M & + \\
\hline $\mathrm{T} 7-13 \mathrm{~F}$ & $X$. campestris pv. phaseoli var. fuscans & Lushoto, Tanzania & M & + \\
\hline $\mathrm{T} 8-2$ & $X$. campestris pv. phaseoli & Arumeru, Tanzania & A & + \\
\hline T8-3 & $X$. campestris pv. phaseoli & Arumeru, Tanzania & A & + \\
\hline $\mathrm{T} 8-4$ & X. campestris pv. phaseoli & Arumeru, Tanzania & A & + \\
\hline $\mathrm{T} 8-5 \mathrm{~F}$ & X. campestris pv. phaseoli var. fuscans & Arumeru, Tanzania & M & + \\
\hline $\mathrm{T} 8-6 \mathrm{~F}$ & X. campestris pv. phaseoli var. fuscans & Arumeru, Tanzania & M & + \\
\hline $\mathrm{T} 8-7 \mathrm{~F}$ & X. campestris pv. phaseoli var. fuscans & Arumeru, Tanzania & M & + \\
\hline
\end{tabular}

\footnotetext{
${ }^{\mathrm{w}}$ Xanthomonas campestris pv. phaseoli, X. campestris pv. phaseoli var. fuscans, and uncharacterized xanthomonad-like bacteria (Xanthomonas spp.).

${ }^{\mathrm{x}} \mathrm{WI}=$ Wisconsin, United States.

y $\mathrm{A}=$ Andean gene pool and $\mathrm{M}=$ Middle American gene pool.

z Pathogenicity was determined by inoculating strains onto trifoliolate leaves of 14-day-old plants (cv. Topcrop) with the razor blade method (29).
} 
plants along a zigzag pattern across all or a portion (fields in Wisconsin) of the field. In most cases, a leaf showing typical CBB symptoms (irregular necrotic lesions with yellow borders and water-soaked spots) was collected from each of 5 to 10 plants in each field, and dried between paper towels. For each leaf sample, tissues $\left(\approx 16 \mathrm{~mm}^{2}\right)$ were excised from the lesion margin, placed in a drop of sterile distilled water on a microscope slide, and macerated. Loopfuls of macerate were streaked onto 523 medium (18) and the plates were incubated at $28^{\circ} \mathrm{C}$. In locations where diseased bean plants were not found (south-central Tanzania), bean seed were collected from local markets and assayed for common blight bacteria with a seed wash dilution plating assay (23).

Four yellow, mucoid, xanthomonad-like colonies were selected from each leaf or seed sample and subcultured on 523 medium. After 2 to 3 days of growth, production of diffusible brown pigment was recorded. To determine if these strains were common blight bacteria, PCR with the $X$. campestris pv. phaseoli- or $X$. campestris pv. phaseoli var. fuscans-specific primer pair $\mathrm{X} 4 \mathrm{c}$ (5'-GGC AAC ACC CGA TCC CTA AAC AGG-3') and X4e (5'-
CGC CGG AAG CAC GAT CCT CGA AG-3') was used. This primer pair directs the amplification of an $\approx 700$-bp fragment from common blight bacteria, but not from other $X$. campestris pathovars, nonpathogenic xanthomonads, or other bacteria associated with common bean (2). Preparation of boiled cell extracts, PCR parameters, and analyses of PCR products have been described previously $(2,4)$.

Additional X. campestris pv. phaseoli and X. campestris pv. phaseoli var. fuscans strains (or total genomic DNA of these strains) were collected previously from East Africa (Uganda and Kenya), Spain, and various New World locations (Brazil, Colombia, the Dominican Republic, Guatemala, Mexico, Puerto Rico, and the United States) (Table 2).

DNA extraction and rep-PCR. Shake cultures from single colonies were grown in $3 \mathrm{ml}$ of yeast tryptone (YT) broth overnight $(12$ to $18 \mathrm{~h})$ at $28^{\circ} \mathrm{C}$. DNA was extracted from bacterial cells using a modification of Silhavy et al. (40). Cells were washed with NE buffer (50 mM Tris-EDTA and $150 \mathrm{mM} \mathrm{NaCl}$ ), resuspended in $\mathrm{NE}$ buffer with proteinase $\mathrm{K}$ at $150 \mu \mathrm{g} / \mathrm{ml}$ and

TABLE 1. (Continued from preceding page)

\begin{tabular}{|c|c|c|c|c|}
\hline Designation & Identity $^{\mathrm{w}}$ & Geographic origin $^{x}$ & Common bean gene pool source ${ }^{y}$ & Pathogenicity ${ }^{z}$ \\
\hline $\mathrm{T} 8-8 \mathrm{~F}$ & X. campestris pv. phaseoli var. fuscans & Arumeru, Tanzania & M & + \\
\hline T8-9F & X. campestris pv. phaseoli var. fuscans & Arumeru, Tanzania & M & + \\
\hline T9-1F & X. campestris pv. phaseoli var. fuscans & Arumeru, Tanzania & M & + \\
\hline T9-2F & X. campestris pv. phaseoli var. fuscans & Arumeru, Tanzania & M & + \\
\hline T9-3 & Xanthomonas spp. & Arumeru, Tanzania & A & - \\
\hline T9-4 & Xanthomonas spp. & Arumeru, Tanzania & A & - \\
\hline $\mathrm{T} 12-3 \mathrm{~F}$ & X. campestris pv. phaseoli var. fuscans & Njiapanda, Tanzania & A & + \\
\hline $\mathrm{T} 12-4 \mathrm{~F}$ & X. campestris pv. phaseoli var. fuscans & Njiapanda, Tanzania & A & + \\
\hline $\mathrm{T} 12-7 \mathrm{~F}$ & X. campestris pv. phaseoli var. fuscans & Njiapanda, Tanzania & A & + \\
\hline $\mathrm{T} 12-8 \mathrm{~F}$ & X. campestris pv. phaseoli var. fuscans & Njiapanda, Tanzania & A & + \\
\hline $\mathrm{T} 12-9 \mathrm{~F}$ & $X$. campestris pv. phaseoli var. fuscans & Njiapanda, Tanzania & M & + \\
\hline $\mathrm{T} 12-10 \mathrm{~F}$ & X. campestris pv. phaseoli var. fuscans & Njiapanda, Tanzania & A & + \\
\hline $\mathrm{T} 12-11 \mathrm{~F}$ & X. campestris pv. phaseoli var. fuscans & Njiapanda, Tanzania & A & + \\
\hline $\mathrm{T} 14-1 \mathrm{~F}$ & X. campestris pv. phaseoli var. fuscans & Karatu, Tanzania & A & + \\
\hline $\mathrm{T} 14-2 \mathrm{~F}$ & X. campestris pv. phaseoli var. fuscans & Karatu, Tanzania & A & + \\
\hline $\mathrm{T} 14-3 \mathrm{~F}$ & X. campestris pv. phaseoli var. fuscans & Karatu, Tanzania & M & + \\
\hline $\mathrm{T} 14-4 \mathrm{~F}$ & X. campestris pv. phaseoli var. fuscans & Karatu, Tanzania & A & + \\
\hline $\mathrm{T} 14-5 \mathrm{~F}$ & X. campestris pv. phaseoli var. fuscans & Karatu, Tanzania & A & + \\
\hline T/Market 8 & $X$. campestris pv. phaseoli & Karatu, Tanzania & A & + \\
\hline $\mathrm{T} 17-1 \mathrm{~F}$ & X. campestris pv. phaseoli var. fuscans & Babati, Tanzania & A & + \\
\hline $\mathrm{T} 17-2 \mathrm{~F}$ & X. campestris pv. phaseoli var. fuscans & Babati, Tanzania & A & + \\
\hline $\mathrm{T} 17-3 \mathrm{~F}$ & X. campestris pv. phaseoli var. fuscans & Babati, Tanzania & A & + \\
\hline $\mathrm{T} 17-4 \mathrm{~F}$ & X. campestris pv. phaseoli var. fuscans & Babati, Tanzania & A & + \\
\hline T/Market 9F & X. campestris pv. phaseoli var. fuscans & Babati, Tanzania & M & + \\
\hline $\mathrm{T} 18-1 \mathrm{~F}$ & X. campestris pv. phaseoli var. fuscans & Endakasi, Tanzania & A & + \\
\hline $\mathrm{T} 18-2 \mathrm{~F}$ & X. campestris pv. phaseoli var. fuscans & Endakasi, Tanzania & A & + \\
\hline $\mathrm{T} 18-3 \mathrm{~F}$ & $X$. campestris pv. phaseoli var. fuscans & Endakasi, Tanzania & A & + \\
\hline $\mathrm{T} 19-1 \mathrm{~F}$ & X. campestris pv. phaseoli var. fuscans & Machame, Tanzania & A & + \\
\hline $\mathrm{T} 19-2 \mathrm{~F}$ & X. campestris pv. phaseoli var. fuscans & Machame, Tanzania & A & + \\
\hline T19-3F & X. campestris pv. phaseoli var. fuscans & Machame, Tanzania & A & + \\
\hline T19-5 & Xanthomonas spp. & Machame, Tanzania & M & - \\
\hline W01 & X. campestris pv. phaseoli & Camel, WI & A & + \\
\hline W02 & X. campestris pv. phaseoli & Camel, WI & A & + \\
\hline W03 & X. campestris pv. phaseoli & Camel, WI & A & + \\
\hline W04 & X. campestris pv. phaseoli & Camel, WI & A & + \\
\hline W05 & X. campestris pv. phaseoli & Camel, WI & A & + \\
\hline W06 & X. campestris pv. phaseoli & Luther, WI & A & + \\
\hline W07 & X. campestris pv. phaseoli & Luther, WI & A & + \\
\hline W08 & X. campestris pv. phaseoli & Luther, WI & A & + \\
\hline W09 & X. campestris pv. phaseoli & Luther, WI & A & + \\
\hline W10 & X. campestris pv. phaseoli & Luther, WI & A & + \\
\hline W11 & X. campestris pv. phaseoli & Luther, WI & A & + \\
\hline W12 & X. campestris pv. phaseoli & Luther, WI & A & + \\
\hline W13 & X. campestris pv. phaseoli & Luther, WI & A & + \\
\hline W14 & X. campestris pv. phaseoli & Luther, WI & A & + \\
\hline W15 & X. campestris pv. phaseoli & Luther, WI & A & + \\
\hline W16 & X. campestris pv. phaseoli & Luther, WI & A & + \\
\hline W17 & X. campestris pv. phaseoli & Rock Falls, WI & A & + \\
\hline W18 & X. campestris pv. phaseoli & Rock Falls, WI & A & + \\
\hline W19 & X. campestris pv. phaseoli & Test Plot, WI & A & + \\
\hline W20 & X. campestris pv. phaseoli & Niece, WI & A & + \\
\hline
\end{tabular}


$20 \%$ sodium dodecyl sulfate (SDS), and incubated at $50^{\circ} \mathrm{C}$ for $1 \mathrm{~h}$. The suspension was extracted with phenol/chloroform/isoamyl alcohol (25:24:1), and DNA was precipitated by the addition of 0.1 volume of $3 \mathrm{M}$ sodium acetate and 1 volume of $100 \%$ isopropanol. DNA was spooled out of the aqueous phase, washed in $70 \%$ ethanol, resuspended in TE buffer $(10 \mathrm{mM}$ Tris and $1 \mathrm{mM}$ EDTA), and quantified using a fluorometer (model TK0100$115 \mathrm{~V}$; Hoefer Scientific Instruments, San Francisco). The repPCR was performed as previously described with the repetitive extragenic palindromic (REP)-PCR primers $1 \mathrm{R}$ (5'-III ICG ICG ICA TCI GGC-3') and 2I (5'-ICG ICT TAT CIG GCC TAC-3'); the enterobacterial repetitive intergenic consensus (ERIC)-PCR primers 1R (5'-ATG TAA GCT CCT GGG GAT TCA C-3') and 2I (5'-AAG TAA GTG ACT GGG GTG AGC G-3'); and the BOX element 1A (BOX)-PCR primer 1R (5'-CTA CGG CAA GGC GAC GCT GAC G-3') (21,30,47).

Pathogenicity tests. To prepare inoculum, selected $X$. campestris pv. phaseoli or $X$. campestris pv. phaseoli var. fuscans strains were streaked onto plates of 523 medium and grown for $48 \mathrm{~h}$ at $28^{\circ} \mathrm{C}$. Cells were suspended in distilled water and adjusted to an optical density at $600 \mathrm{~nm}=0.50$, which corresponds to $\approx 10^{8} \mathrm{CFU} / \mathrm{ml}$. Two types of pathogenicity tests were performed: (i) basic pathogenicity on common bean, in which strains were inoculated onto the susceptible cv. Topcrop; and (ii) differential pathogenicity, in which strains were inoculated onto genotypes representing the two common bean gene pools. The differential pathogenicity tests involved cvs. Topcrop and White Kidney (Andean), Black Turtle Soup and Sutter Pink (Middle American), and a number of Malawian (22-2 and 12-4 [Andean]; and 1-1, 6-5, and Namajengo [Middle American]) and Tanzanian (Rose Koko [Andean]) genotypes.
Five seed of each genotype were planted in 6-in. pots. The razor blade method (28) was used to inoculate the first fully expanded trifoliolate leaves of bean plants $(\approx 14$ days after planting). The floor of the greenhouse was kept wet to generate humidity to favor development of CBB. Symptoms were rated 10 days after inoculation using the following rating scale: $1=$ no visual symptoms or slight marginal necrosis; 2 = water-soaking, chlorosis, or necrosis (blight) in $<25 \%$ of the inoculated area; $3=25$ to $50 \%$ blight; and $4=>50 \%$ blight.

RFLP analysis. Approximately $2 \mu \mathrm{g}$ of total genomic DNA was digested with EcoRI as specified by the manufacturer (Life Technologies, Rockville, MD). Digested DNA was fractionated in $0.7 \%$ agarose gels in Tris-Borate-EDTA (TBE) buffer at $35 \mathrm{~V}$ for $20 \mathrm{~h}$ and stained with ethidium bromide. Southern blotting was performed as previously described $(11,35)$. Recombinant plasmids $\mathrm{P} 2$ and P7, which contain repetitive sequences cloned from the $X$. campestris pv. phaseoli genome $(11,12)$, were labeled with $\left[\alpha-{ }^{32} \mathrm{P}\right] \mathrm{dCTP}$ by nick translation (Life Technologies) and used as probes. Southern blot hybridization analysis was performed under low-stringency conditions as previously described $(11,35)$. Membranes were air dried and exposed to Fuji Rx NIF X-ray film.

Determination of the common bean gene pool. To determine the gene pool of the bean plants from which common blight bacteria were isolated, total genomic DNA was extracted from $\approx 10 \mathrm{mg}$ of dried leaf tissue. After grinding dried tissue in liquid nitrogen, DNA was extracted using the Dellaporta method (7), except that an additional chloroform:isoamyl alcohol extraction was performed before DNA was precipitated. Total genomic DNA was used in the PCR with the $J_{1} d_{1} / J_{1} d_{2}$ primer pair, which directs the amplification of an $\approx 1.6-\mathrm{kb}$ DNA fragment from Andean beans and an $\approx 1.3-\mathrm{kb}$ fragment from Middle American beans

TABLE 2. Additional strains of Xanthomonas campestris pv. phaseoli and X. campestris pv. phaseoli var. fuscans used in this study

\begin{tabular}{|c|c|c|c|}
\hline Strain & Identity & Geographical origin & Source \\
\hline $\mathrm{CNF} 30^{\mathrm{x}}$ & X. campestris pv. phaseoli & Brazil & 11 \\
\hline CNF27y & $X$. campestris pv. phaseoli & Brazil & 11 \\
\hline $\mathrm{ES}^{\mathrm{y}}$ & $X$. campestris pv. phaseoli & Brazil & 11 \\
\hline $\mathrm{XP} 15^{\mathrm{x}}$ & $X$. campestris pv. phaseoli & Brazil & 11 \\
\hline $147^{x}$ & $X$. campestris pv. phaseoli & Brazil & M. A. Pastor-Corrales (CIAT) \\
\hline $151^{\mathrm{x}}$ & $X$. campestris pv. phaseoli & Brazil & M. A. Pastor-Corrales (CIAT) \\
\hline $153^{x}$ & X. campestris pv. phaseoli & Brazil & M. A. Pastor-Corrales (CIAT) \\
\hline$X 50^{x}$ & X. campestris pv. phaseoli & Colombia & 11 \\
\hline $123^{x}$ & X. campestris pv. phaseoli & Colombia & M. A. Pastor-Corrales (CIAT) \\
\hline $321^{x}$ & X. campestris pv. phaseoli & Colombia & M. A. Pastor-Corrales (CIAT) \\
\hline $258^{x}$ & $X$. campestris pv. phaseoli & Dominican Republic & M. A. Pastor-Corrales (CIAT) \\
\hline $259^{x}$ & X. campestris pv. phaseoli & Dominican Republic & M. A. Pastor-Corrales (CIAT) \\
\hline $260^{x}$ & X. campestris pv. phaseoli & Dominican Republic & M. A. Pastor-Corrales (CIAT) \\
\hline $\mathrm{X} 21^{\mathrm{x}}$ & X. campestris pv. phaseoli & Kenya & R. B. Mabagala \\
\hline $52^{\mathrm{x}}$ & $X$. campestris pv. phaseoli & Mexico & M. A. Pastor-Corrales (CIAT) \\
\hline $55^{x}$ & $X$. campestris pv. phaseoli & Mexico & M. A. Pastor-Corrales (CIAT) \\
\hline $\mathrm{P} 1^{\mathrm{y}}$ & $X$. campestris pv. phaseoli & Puerto Rico & R. L. Gilbertson \\
\hline S659 & $X$. campestris pv. phaseoli & Spain & R. Lopez Perez \\
\hline $\mathrm{X} 17^{\mathrm{x}}$ & X. campestris pv. phaseoli & Uganda & R. B. Mabagala \\
\hline $\mathrm{X} 47^{\mathrm{x}}$ & X. campestris pv. phaseoli & Uganda & 11 \\
\hline $\mathrm{X} 45^{\mathrm{x}}$ & X. campestris pv. phaseoli & Florida, USA & 11 \\
\hline $193^{x}$ & X. campestris pv. phaseoli & USA & M. A. Pastor-Corrales (CIAT) \\
\hline $332 F^{x}$ & $X$. campestris pv. phaseoli var. fuscans & Brazil & M. A. Pastor-Corrales (CIAT) \\
\hline $91 \mathrm{~F}^{\mathrm{x}}$ & $X$. campestris pv. phaseoli var. fuscans & Colombia & M. A. Pastor-Corrales (CIAT) \\
\hline $110 \mathrm{~F}^{\mathrm{x}}$ & $X$. campestris pv. phaseoli var. fuscans & Colombia & M. A. Pastor-Corrales (CIAT) \\
\hline $\mathrm{XCPFG} 44^{\mathrm{x}}$ & X. campestris pv. phaseoli var. fuscans & Guatemala & 11 \\
\hline $\mathrm{X} 25^{\mathrm{x}}$ & X. campestris pv. phaseoli var. fuscans & Kenya & R. B. Mabagala \\
\hline $116 \mathrm{~F}^{\mathrm{x}}$ & $X$. campestris pv. phaseoli var. fuscans & Puerto Rico & M. A. Pastor-Corrales (CIAT) \\
\hline $\mathrm{P} 2 \mathrm{~F}^{\mathrm{y}}$ & $X$. campestris pv. phaseoli var. fuscans & Puerto Rico & R. L. Gilbertson \\
\hline SITA920x & $X$. campestris pv. phaseoli var. fuscans & Spain & R. Lopez Perez \\
\hline $\mathrm{T} 123 \mathrm{~F}^{\mathrm{z}}$ & $X$. campestris pv. phaseoli var. fuscans & Tanzania & This study (collected 2002) \\
\hline MIF $1^{y}$ & $X$. campestris pv. phaseoli var. fuscans & Michigan, USA & 11 \\
\hline $\mathrm{XCPFN}^{\mathrm{x}}$ & $X$. campestris pv. phaseoli var. fuscans & Nebraska, USA & 11 \\
\hline WF8y & $X$. campestris pv. phaseoli var. fuscans & Wisconsin, USA & 11 \\
\hline
\end{tabular}

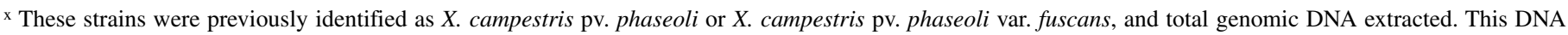
was used in repetitive polymerase chain reaction (rep-PCR), Southern blot hybridization, or both.

y These strains were used in rep-PCR analyses and in pathogenicity tests.

$\mathrm{z}$ This strain was isolated and characterized in the present study. Total genomic DNA was extracted and used in Southern blot hybridization analysis.
} 
(17). The PCR profile used was 1 cycle of $94^{\circ} \mathrm{C}$ for $2 \mathrm{~min} ; 40 \mathrm{cy}-$ cles of $94^{\circ} \mathrm{C}$ for $30 \mathrm{~s}, 58^{\circ} \mathrm{C}$ for $1 \mathrm{~min}$, and $72^{\circ} \mathrm{C}$ for $2 \mathrm{~min}$; followed by an extension cycle of $72^{\circ} \mathrm{C}$ for $5 \mathrm{~min}$. PCR products were fractionated in $1.0 \%$ agarose gels in TBE buffer, stained with ethidium bromide, and examined with a gel imaging system (model IS-1000; Alpha Innotech Corporation, San Leandro, CA).

\section{RESULTS}

Collection of leaf and seed samples and isolation of common blight bacteria. Three surveys were conducted in East Africa (Malawi and Tanzania) to obtain samples for isolation of common blight bacteria. The incidence of CBB was low in some fields surveyed in south-central Tanzania, and seed samples were collected from local markets and assayed for common blight bacteria. Common blight bacteria were isolated from leaves on 523 medium and classified as xanthomonad-like based on having a yellow, convex, mucoid colony morphology.

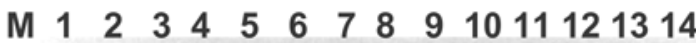

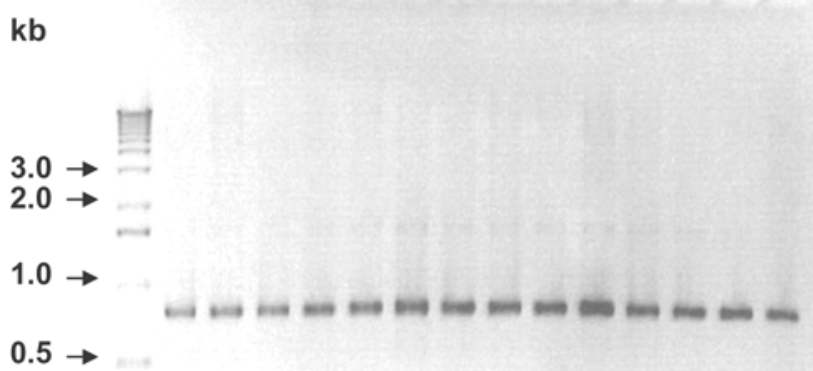

Fig. 1. Agarose gel showing polymerase chain reaction products amplified from total genomic DNA of strains of Xanthomonas campestris pv. phaseoli and $X$. campestris pv. phaseoli var. fuscans with the $\mathrm{X} 4 \mathrm{c} / \mathrm{X} 4 \mathrm{e}$ primer pair. Lane M: size markers (1-kb ladder, Gibco-BRL). Lane 1: M11 (Malawi X. campestris pv. phaseoli); lane 2: M12F (Malawi X. campestris pv. phaseoli var. fuscans); lanes 3 to 6: M19, M20, M25, and M30 (Malawi X. campestris pv. phaseoli); lane 7: T14 (Tanzania $X$. campestris pv. phaseoli); lanes 8 to 10: T17F, T19F, and T20F (Tanzania X. campestris pv. phaseoli var. fuscans); lanes 11 and 12: T21 and T8-3 (Tanzania $X$. campestris pv. phaseoli); lane 13: P1 (Puerto Rico X. campestris pv. phaseoli); and lane 14: P2F (Puerto Rico X. campestris pv. phaseoli var. fuscans).
The first survey was conducted in Malawi and Tanzania in 1997. Twenty-one xanthomonad-like strains were isolated from bean leaves from seven fields in five locations in north-central Malawi (strains with ' $M$ ' designation in Table 1), and two additional strains were isolated from south-central Tanzania: one from a leaf sample (strain T22F) and another from a seed sample (strain T21F). The second survey (Tanzania I) was conducted in south-central Tanzania in 1998, and eight strains (T3F, T14, T17F, T19F, T20F, T21, T23F, and T32F) (Table 1) were isolated from bean leaves from a number of fields of cv. Rose Koko beans. The third survey (Tanzania II) was conducted in south-central and northern Tanzania in 2000, and 46 strains (remainder of the strains with ' $\mathrm{T}$ ' designation in Table 1) were isolated from bean leaves from eight fields in different geographical locations. A fourth survey was conducted in north-central Wisconsin in 2002, and 20 strains (strains with ' $\mathrm{W}$ ' designation in Table 1) were isolated from bean leaves from five fields of dark red kidney beans.

Identification of common blight bacteria. Xanthomonad-like bacteria were subcultured on 523 medium, and strains that produced a brown pigment were tentatively identified as $X$. campestris pv. phaseoli var. fuscans. Further identification of $X$. campestris pv. phaseoli and $X$. campestris pv. phaseoli var. fuscans strains was based on amplification of the $\approx 700$-bp DNA fragment with the X4c/X4e primer pair (Fig. 1) and pathogenicity on common bean. All brown-pigmented xanthomonad-like bacteria were confirmed as $X$. campestris pv. phaseoli var. fuscans strains based on being PCR positive (i.e., the $\approx 700$-bp fragment was amplified) and pathogenic on common bean (Table 3). Strains that did not produce a brown pigment were either $X$. campestris pv. phaseoli or nonpathogenic xanthomonads. The $X$. campestris pv. phaseoli strains were PCR positive and pathogenic on common bean, whereas the nonpathogenic xanthomonads were PCR negative and did not induce symptoms on common bean (Table 3). Together, the results of these tests (i) allowed for the identification of X. campestris pv. phaseoli and X. campestris pv. phaseoli var. fuscans strains and (ii) provided further evidence that PCR with the $\mathrm{X} 4 \mathrm{c} / \mathrm{X} 4 \mathrm{e}$ primer pair is an accurate means of detecting common blight bacteria and differentiating them from nonpathogenic xanthomonads that can be associated with common bean ( 2 , 11,13).

Of the 23 strains collected in the first survey ( 21 from Malawi and 2 from Tanzania), 11 were $X$. campestris pv. phaseoli, 9 were $X$. campestris pv. phaseoli var. fuscans (including $\mathrm{T} 21 \mathrm{~F}$ and $\mathrm{T} 22 \mathrm{~F}$ from Tanzania), and 3 were nonpathogenic xanthomonads. Of the 54 strains collected from Tanzania in the Tanzania I and II sur-

TABLE 3. Characterization of xanthomonad-like strains isolated from common bacterial blight samples collected during surveys of East Africa and Wisconsin

\begin{tabular}{|c|c|c|c|c|c|}
\hline \multirow[b]{2}{*}{ Survey, strains ${ }^{x}$} & \multirow[b]{2}{*}{ Number } & \multirow[b]{2}{*}{ PCR detection/pathogenicity ${ }^{y}$} & \multicolumn{3}{|c|}{ Common bean gene pool ${ }^{\mathrm{z}}$} \\
\hline & & & Andean & Mesoamerican & Not determined \\
\hline \multicolumn{6}{|l|}{ Malawi, Tanzania } \\
\hline$X$. campestris pv. phaseoli & 11 & $11 / 11$ & 7 & 1 & 3 \\
\hline X. campestris pv. phaseoli var. fuscans & 9 & $9 / 9$ & 2 & 7 & 0 \\
\hline Xanthomonas spp. & 3 & $0 / 3$ & 3 & 0 & 0 \\
\hline \multicolumn{6}{|l|}{ Tanzania I } \\
\hline X. campestris pv. phaseoli & 2 & $2 / 2$ & 2 & 0 & 0 \\
\hline X. campestris pv. phaseoli var. fuscans & 6 & $6 / 6$ & 6 & 0 & 0 \\
\hline \multicolumn{6}{|l|}{ Tanzania II } \\
\hline X. campestris pv. phaseoli & 4 & $4 / 4$ & 4 & 0 & 0 \\
\hline X. campestris pv. phaseoli var. fuscans & 35 & $35 / 35$ & 21 & 14 & 0 \\
\hline Xanthomonas spp. & 7 & $0 / 7$ & 3 & 4 & 0 \\
\hline \multicolumn{6}{|l|}{ Wisconsin } \\
\hline X. campestris pv. phaseoli & 20 & $20 / 20$ & 20 & 0 & 0 \\
\hline \multicolumn{6}{|c|}{$\begin{array}{l}\text { y Polymerase chain reaction (PCR) detection and pathogenicity. PCR detection was based upon amplification of an } \approx 700 \text { bp DNA fragment with the X4c/X } \\
\text { primer pair. Pathogenicity on common bean was determined by inoculating strains onto trifoliolate leaves of } 14-\text { day-old plants (cv. Topcrop) with the raz } \\
\text { blade method (29). Note that all strains detected by PCR and this primer pair were pathogenic on common bean, whereas strains that were not detected by PC } \\
\text { were not pathogenic. }\end{array}$} \\
\hline
\end{tabular}


veys, 41 were $X$. campestris pv. phaseoli var. fuscans, 6 were $X$. campestris pv. phaseoli, and 7 were nonpathogenic xanthomonads. All 20 strains collected from red kidney beans in the Wisconsin survey were $X$. campestris pv. phaseoli (Table 3 ).

rep-PCR analysis. Two distinct rep-PCR fingerprints were generated (with all three rep-PCR primers) for $X$. campestris pv. phaseoli strains collected in Malawi in 1997, whereas a third fingerprint was generated for a New World $X$. campestris pv. phaseoli strain from Puerto Rico (Table 2, strain P1) (Fig. 2 and data not shown). These results indicated that $X$. campestris pv. phaseoli is composed of at least three distinct genotypes. Six $X$. campestris pv. phaseoli strains were collected from Tanzania in the Tanzania

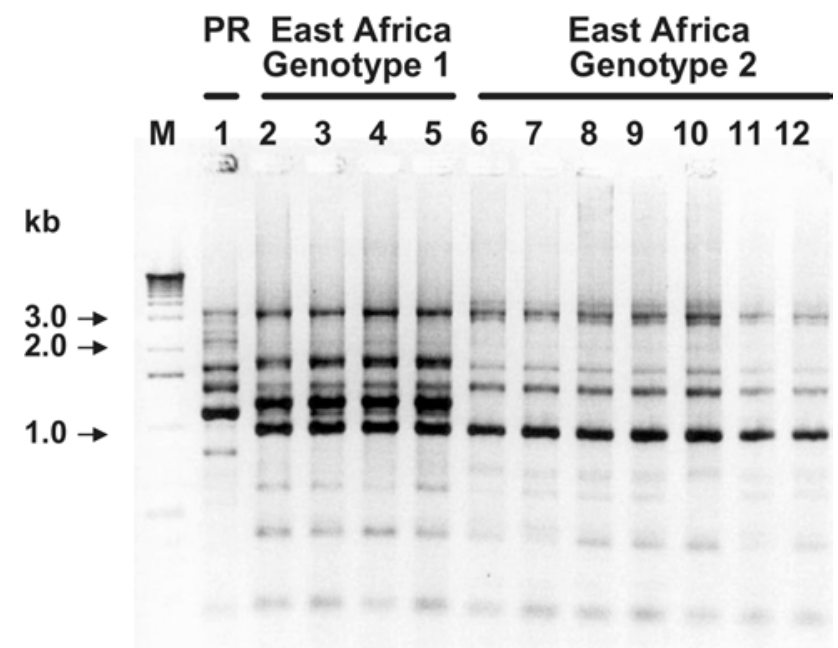

Fig. 2. Agarose gel showing polymerase chain reaction fingerprint patterns generated from total genomic DNA of Xanthomonas campestris pv. phaseoli strains from East Africa and Puerto Rico with repetitive extragenic palindromic primers. Lane M: size markers (1-kb ladder, Gibco-BRL). Lane 1: P1 (Puerto Rico); lanes 2 to 5: East African genotype 1: M11, M19, M20 (Malawi), and T14 (Tanzania); lanes 6 to 12: East African genotype 2: M17, M18, M24, M25, M29, M30 (Malawi), and T21 (Tanzania).
I and II surveys. Three strains (T14, T21, and T/Market 8) had rep-PCR fingerprints identical to one of the two fingerprints of the Malawi X. campestris pv. phaseoli strains, whereas the other three strains (T8-2, T8-3, and T8-4; collected from a single field in Arumeru in 2000) had fingerprints identical to that of the P1 $X$. campestris pv. phaseoli strain (Fig. 3 and data not shown). The 20 X. campestris pv. phaseoli strains from dark red kidney beans in Wisconsin had rep-PCR fingerprints identical to that of the P1 $X$. campestris pv. phaseoli strain.

To determine if the fingerprint of the $\mathrm{P} 1 X$. campestris $\mathrm{pv}$. phaseoli strain was representative of $X$. campestris pv. phaseoli strains from other geographical locations, rep-PCR analysis was performed on total genomic DNA of $X$. campestris pv. phaseoli strains from various New and Old World locations (Table 2). $X$. campestris pv. phaseoli strains from Brazil (seven strains), Colombia (three strains), the Dominican Republic (three strains), Mexico (two strains), Spain (one strain), and the United States (two strains) had rep-PCR fingerprints similar to or indistinguishable from that of the P1X. campestris pv. phaseoli strain (Fig. 3 and data not shown). In contrast, strains from Kenya (one strain) and Uganda (two strains) had fingerprints identical to one of the two fingerprints of the Malawi $X$. campestris pv. phaseoli strains (Fig. 3 and data not shown). Together, these results indicate that $X$. campestris pv. phaseoli is a heterogeneous pathovar composed of three genetically distinct genotypes: two found in East Africa (East African genotypes 1 and 2) and another representing strains from all other locations, including Tanzania.

A different situation was found for $X$. campestris pv. phaseoli var. fuscans strains. First, the fingerprint for $X$. campestris pv. phaseoli var. fuscans strains was considerably different from those of the X. campestris pv. phaseoli strains (all three genotypes) (Fig. 3), which is consistent with $X$. campestris pv. phaseoli and $X$. campestris pv. phaseoli var. fuscans being genetically distinct. All X. campestris pv. phaseoli var. fuscans strains from Malawi and Tanzania had rep-PCR fingerprints that were identical or nearly identical to each other (Fig. 4 and data not shown). Furthermore, the fingerprints of these East African X. campestris pv. phaseoli var. fuscans strains also were identical or nearly
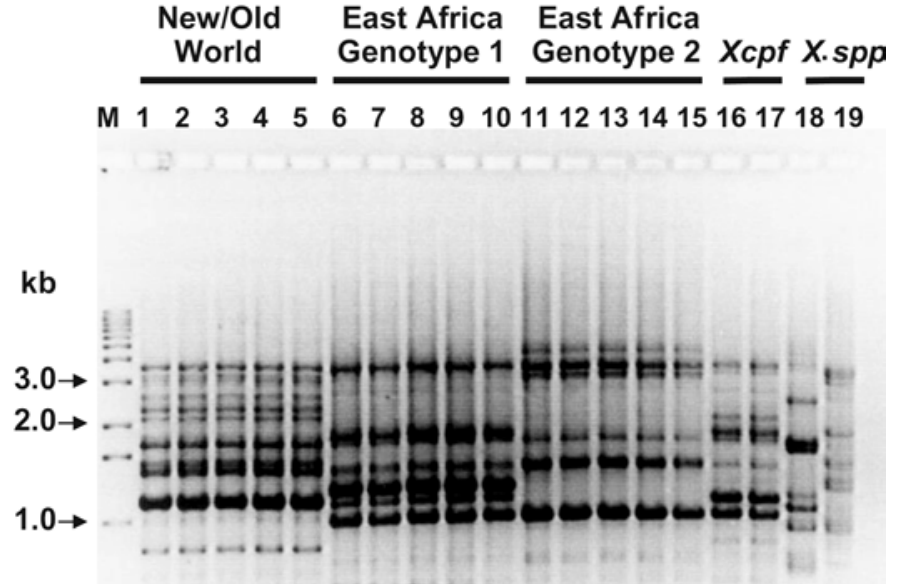

Fig. 3. Agarose gel showing polymerase chain reaction fingerprint patterns generated from total genomic DNA of Xanthomonas campestris pv. phaseoli, $\mathrm{X}$. campestris pv. phaseoli var. fuscans (Xcpf), and nonpathogenic Xanthomonas (X. spp.) strains with repetitive extragenic palindromic primers. Lane M: size markers (1-kb ladder, Gibco-BRL). Lanes 1 to 5: X. campestris pv. phaseoli strains: P1 (Puerto Rico), CNF27 (Brazil), 123 (Colombia), 193 (United States), and T8-2 (Tanzania); lanes 6 to 10: East African genotype 1: M11, M19, and M20 (Malawi), T14 (Tanzania), and X17 (Uganda); lanes 11 to 15: East African genotype 2: M17 and M18 (Malawi), X21 (Kenya), and T21 and T/Market 8 (Tanzania); lanes 16 to 17: X. campestris pv. phaseoli var. fuscans strains: M12F and M13F (Malawi); and lanes 18 and 19: Xanthomonas spp.: T3-3 and T3-4.

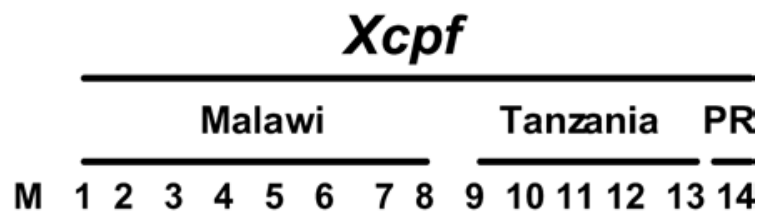

$\mathbf{k b}$

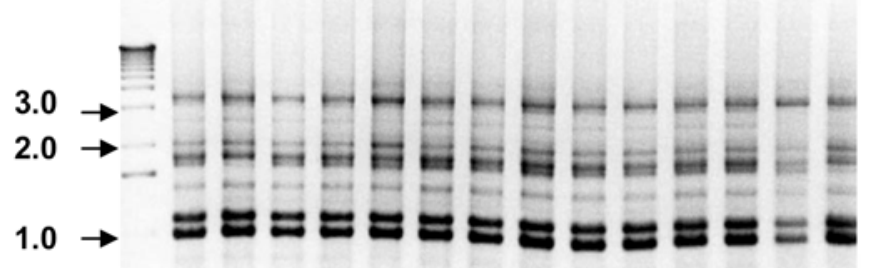

Fig. 4. Agarose gel showing polymerase chain reaction fingerprint patterns generated from total genomic DNA of Xanthomonas campestris pv. phaseoli var. fuscans (Xcpf) strains from East Africa and Puerto Rico with repetitive extragenic palindromic primers. Lane $\mathrm{M}$ : size markers (1-kb ladder, GibcoBRL). Lanes 1 to 4 and 7 to 8: M12F, M13F, M14F, M16F, M26F, and M31F from Malawi; lanes 5 to 6 and 9 to 13: T21F, T22F, T17F, T19F, T20F, T23F, and T32F from Tanzania; and lane 14: P2F from Puerto Rico (PR). 
identical to fingerprints of $X$. campestris pv. phaseoli var. fuscans strains from Brazil (one strain), Colombia (two strains), Guatemala (one strain), Kenya (one strain), Puerto Rico (one strain), Spain (one strain), and the United States (three strains) (Fig. 4 and data not shown). Thus, in contrast to X. campestris pv. phaseoli, $X$. campestris pv. phaseoli var. fuscans strains from East Africa and the New World composed a genetically homogeneous group.

Analysis of selected nonpathogenic xanthomonads by rep-PCR revealed distinct fingerprints for each strain, and these fingerprints were distinct from those of $X$. campestris pv. phaseoli and $X$. campestris pv. phaseoli var. fuscans strains (Fig. 3 and data not shown). Thus, these results supported those of pathogenicity tests and PCR, indicating that these strains are genetically distinct nonpathogenic xanthomonad-like bacteria.

RFLP analysis. Strains representing the genetic and geographic diversity detected among common blight bacteria by repPCR analysis were selected for Southern blot hybridization analysis with the repetitive DNA probes $\mathrm{P} 2$ and $\mathrm{P} 7$. The $\mathrm{P} 2$ probe hybridized to multiple ( $>10)$ EcoRI fragments of the $X$. campestris pv. phaseoli strains from the New World, Spain (strain S659), and Tanzania (T8-3, one of the strains with the New World-type fingerprint), and different hybridization patterns were observed among these strains (Fig. 5). In contrast, this probe hybridized to only a single similar-sized fragment from strains of the two East African X. campestris pv. phaseoli genotypes (Fig. 5). This was consistent with results of rep-PCR analyses showing genetic diversity between the East African $X$. campestris pv. phaseoli genotypes and $X$. campestris pv. phaseoli strains from other (mostly New World) locations. The P2 probe did not reveal genetic diversity among strains of the East African genotypes.

The P7 probe also hybridized with multiple DNA fragments of the $X$. campestris pv. phaseoli strains from the New World, Spain, and Tanzania (strain T8-3). Some hybridizing fragments were shared among strains, but most were polymorphic, revealing genetic diversity among these $X$. campestris pv. phaseoli strains (Fig. 6). The P7 probe hybridized to fewer fragments in the East African genotypes, thereby differentiating these genotypes from
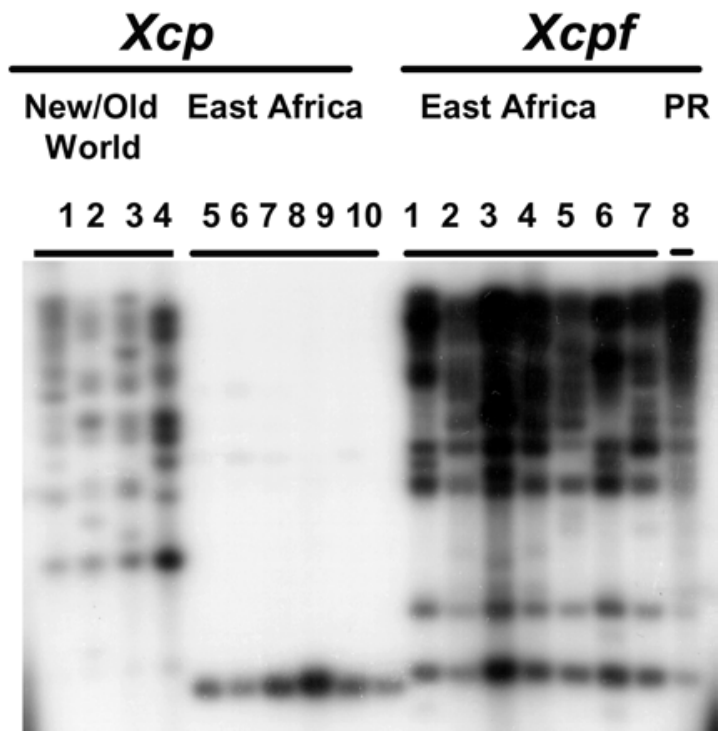

Fig. 5. Southern blot hybridization analysis of EcoRI-digested total genomic DNA of strains of Xanthomonas campestris pv. phaseoli (Xcp) and X. campestris pv. phaseoli var. fuscans $(X c p f)$ with a repetitive element probe (P2). $X$. campestris pv. phaseoli strains: lanes 1 to 4: P1 (Puerto Rico), S659 (Spain), W01 (United States), and T8-3 (Tanzania); lanes 5 to 7: East African genotype 1: M11 and M19 (Malawi) and T14 (Tanzania); lanes 8 to 10: East African genotype 2: M17 and M30 (Malawi) and T21 (Tanzania); X. campestris pv. phaseoli var. fuscans strains: lanes 1 to 8: M12F and M13F (Malawi), T22F (Tanzania), M31 (Malawi), T17F, T20F, and T123F (Tanzania), and P2F (Puerto Rico, PR). other $X$. campestris pv. phaseoli strains. This probe also differentiated strains of the two East African genotypes (Fig. 6).

The P2 probe hybridized to multiple DNA fragments $(>10)$ in all $X$. campestris pv. phaseoli var. fuscans strains, and the hybridization pattern clearly was distinct from those of the $X$. campestris pv. phaseoli strains (Fig. 5). Five fragments were shared among all $X$. campestris pv. phaseoli var. fuscans strains, whereas the others were polymorphic. This indicates genetic diversity among $X$. campestris pv. phaseoli var. fuscans strains. However, both the rep-PCR and RFLP analyses did not reveal genetically distinct East African X. campestris pv. phaseoli var. fuscans strains. Similar results were obtained for the $\mathrm{P} 7$ probe, although it hybridized with considerably fewer $X$. campestris pv. phaseoli var. fuscans DNA fragments compared with the $\mathrm{P} 2$ probe (Fig. 6).

Interaction of $X$. campestris pv. phaseoli and $X$. campestris pv. phaseoli var. fuscans strains with the common bean host. Two approaches were used to analyze the interaction of common blight bacteria and the common bean plant. First, the gene pool of the bean plant from which each strain was isolated was determined using PCR and the $J_{1} d_{1} / J_{1} d_{2}$ primer pair, which direct the amplification of different-sized DNA fragments from Andean and Middle American beans. The results are presented in Tables 1 and 3. X. campestris pv. phaseoli and X. campestris pv. phaseoli var. fuscans strains from Malawi were isolated predominantly from Andean and Middle American beans, respectively (Table 3). In contrast, the majority of common blight bacteria from Tanzania were $X$. campestris pv. phaseoli var. fuscans (i.e., 43 of 49 strains), and these were isolated from beans of both gene pools. All six strains of $X$. campestris pv. phaseoli from Tanzania were isolated from Andean beans, and only X. campestris pv. phaseoli was isolated from the Andean red kidney bean plants in Wisconsin (Table 3). Finally, the $\mathrm{P} 1 X$. campestris pv. phaseoli and $\mathrm{P} 2 \mathrm{~F}$ $X$. campestris pv. phaseoli var. fuscans strains from Puerto Rico were isolated from Andean and Middle American beans, respectively. Taken together, these results indicate that $X$. campestris pv. phaseoli was associated predominantly with Andean beans (note that only a single $X$. campestris pv. phaseoli strain, M30 from
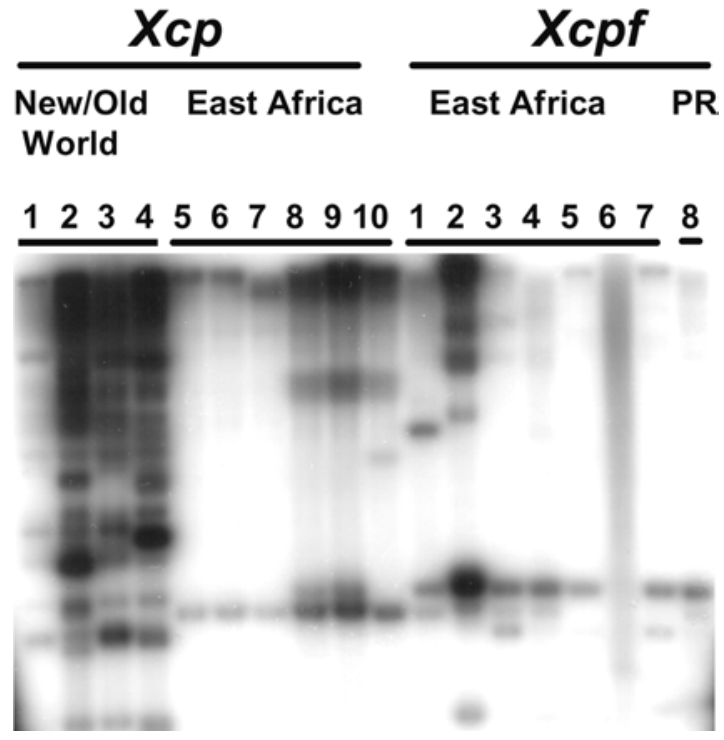

Fig. 6. Southern blot hybridization analysis of EcoRI-digested total genomic DNA of strains of Xanthomonas campestris pv. phaseoli (Xcp) and X. campestris pv. phaseoli var. fuscans (Xcpf) with a repetitive element probe (P7). X. campestris pv. phaseoli strains: lanes 1 to 4: P1 (Puerto Rico), S659 (Spain), W01 (United States), and T8-3 (Tanzania); lanes 5 to 7: East African genotype 1: M11 and M19 (Malawi) and T14 (Tanzania); lanes 8 to 10: East African genotype 2: M17 and M30 (Malawi) and T21 (Tanzania); X. campestris pv. phaseoli var. fuscans strains: lanes 1 to 8 : $\mathrm{M} 12 \mathrm{~F}$ and $\mathrm{M} 13 \mathrm{~F}$ (Malawi), T22F (Tanzania), M31F (Malawi), T17F, T20F, and T123F (Tanzania), and P2F (Puerto Rico, PR). 
Malawi, was isolated from Middle American beans). X. campestris pv. phaseoli var. fuscans was the predominant common blight bacterium isolated from Middle American beans, but it also was commonly isolated from Andean beans in Tanzania (Tables 1 and 3).

Pathogenicity tests. The host-pathogen interaction was investigated by inoculating $X$. campestris pv. phaseoli and X. campestris pv. phaseoli var. fuscans strains, representing the genetic diversity revealed by rep-PCR and RFLP analyses, onto a series of Andean and Middle American beans. Strain M11 was an East African genotype $1 X$. campestris pv. phaseoli strain, P1 was a New World $X$. campestris pv. phaseoli strain, M12F was an East African X. campestris pv. phaseoli var. fuscans strain, and P2F was a New World $X$. campestris pv. phaseoli var. fuscans strain. Overall, the New World X. campestris pv. phaseoli strain (P1) was significantly more pathogenic (mean disease rating [MDR] of 3.8 on a 4-point scale) than the East African $X$. campestris pv. phaseoli strain (M11) (MDR of 2.9) (Table 4). The New World X. campestris pv. phaseoli strain was highly pathogenic on Andean and Middle American beans (MDR of 3.8); whereas the East African X. campestris pv. phaseoli strain was highly pathogenic on Andean beans (MDR of 3.4), but was significantly less pathogenic on Middle American beans (MDR of 2.4). Moreover, the East African X. campestris pv. phaseoli strain was more pathogenic on Middle American beans from East Africa (MDR of 2.9) than on the two Middle American cultivars from the United States (MDR of 1.6) (Table 4).

In a similar experiment, replicated five times, the pathogenicity of strains M11 and M17, representing the East African X. campestris pv. phaseoli genotypes 1 and 2, respectively, and two East African $X$. campestris pv. phaseoli var. fuscans strains (M13F and T22F) were compared with two New World X. campestris pv. phaseoli strains from Brazil (CNF27 and ES5) and two $X$. campestris pv. phaseoli var. fuscans strains from the United States (WF8 and MIF1). Both East African X. campestris pv. phaseoli strains were significantly more pathogenic on Andean beans (MDR of 3.1 for M11 and 3.2 for M17) than on Middle American beans (MDR of 1.7 for M11 and 2.6 for M17). Furthermore, strain M17 (genotype 2) was significantly more pathogenic than M11 (genotype 1) on Middle American beans. In contrast, the two New World $X$. campestris pv. phaseoli strains from Brazil were highly pathogenic on Andean and Middle American beans (MDR of 4.0 for CNF27 and 3.9 for ES5).

Strains of $X$. campestris pv. phaseoli var. fuscans from East Africa $(\mathrm{M} 12 \mathrm{~F})$ and the New World (P2F) were highly pathogenic on Andean and Middle American beans, with overall MDRs of 3.8 and 4.0, respectively (Table 4). Similar results were obtained for the two X. campestris pv. phaseoli var. fuscans strains from the Unites States (MDRs of 3.9 for WF8 and MIF1 on Andean and Middle American beans), and for two additional X. campestris pv. phaseoli var. fuscans strains from East Africa (MDRs of 3.9 for $\mathrm{M} 13 \mathrm{~F}$ and $\mathrm{T} 22 \mathrm{~F}$ on Andean and Middle American beans).

Together, these results indicate that differences in pathogenicity exist between $X$. campestris pv. phaseoli strains representing the East African genotypes and those representing the other (New World) genotype, which is consistent with the genetic diversity detected among these genotypes. No differences in pathogenicity were detected among East African and New World X. campestris pv. phaseoli var. fuscans strains, consistent with the lack of genetic diversity detected among these strains. X. campestris pv. phaseoli var. fuscans strains were significantly more pathogenic than the East African X. campestris pv. phaseoli strains, but not the New World X. campestris pv. phaseoli strains (Table 4).

\section{DISCUSSION}

Genetic variability of $X$. campestris pv. phaseoli and $X$. campestris pv. phaseoli var. fuscans strains. It long has been

TABLE 4. Mean disease ratings for East African and New World strains of Xanthomonas campestris pv. phaseoli and X. campestris pv. phaseoli var. fuscans inoculated onto Andean and Middle American common bean (Phaseolus vulgaris) genotypes

\begin{tabular}{|c|c|c|c|c|c|}
\hline \multirow[b]{3}{*}{ Bean gene pool, cultivar, line } & \multicolumn{4}{|c|}{ Bacterial strains and pathogenicity tests ${ }^{\mathrm{x}}$} & \multirow[b]{3}{*}{ Overall mean ${ }^{y}$} \\
\hline & \multicolumn{2}{|c|}{ X. campestris pv. phaseoli } & \multicolumn{2}{|c|}{ X. campestris pv. phaseoli var. fuscans } & \\
\hline & M11 & $\mathrm{P} 1$ & $\mathrm{M} 12 \mathrm{~F}$ & $\mathrm{P} 2 \mathrm{~F}$ & \\
\hline U.S. genotypes & & & & & \\
\hline White Kidney & 3.8 & 3.8 & 3.3 & 3.6 & $3.6 \mathrm{a}$ \\
\hline Topcrop & 3.3 & 3.9 & 3.9 & 3.7 & $3.7 \mathrm{a}$ \\
\hline Mean & 3.7 & 3.9 & 3.6 & 3.7 & 3.7 \\
\hline $22-2$ & 3.0 & 3.8 & 3.9 & 3.9 & $3.6 \mathrm{a}$ \\
\hline $12-4$ & 3.5 & 3.6 & 3.3 & 3.7 & $3.6 \mathrm{a}$ \\
\hline Mean & 3.3 & 3.8 & 3.6 & 3.4 & 3.6 \\
\hline Overall Andean mean & 3.4 & 3.8 & 3.6 & 3.7 & 3.6 \\
\hline \multicolumn{6}{|l|}{ Middle American } \\
\hline \multicolumn{6}{|l|}{ U.S. genotypes } \\
\hline Sutter Pink & 1.5 & 3.7 & 3.6 & 3.8 & $3.1 \mathrm{~b}$ \\
\hline $6-5$ & 2.6 & 3.9 & 3.5 & 3.6 & $3.4 \mathrm{ab}$ \\
\hline $1-1$ & 3.1 & 3.5 & 3.7 & 3.7 & $3.5 \mathrm{ab}$ \\
\hline Mean & 2.8 & 3.8 & 3.7 & 3.6 & 3.5 \\
\hline Overall Middle American mean & 2.4 & 3.8 & 3.7 & 3.7 & 3.4 \\
\hline Overall mean ${ }^{z}$ & $2.9 \mathrm{~b}$ & $3.8 \mathrm{a}$ & $3.6 \mathrm{a}$ & $3.7 \mathrm{a}$ & 3.5 \\
\hline
\end{tabular}

${ }^{\mathrm{x}}$ Plants were inoculated with an aqueous suspension $\left(1 \times 10^{8} \mathrm{CFU} / \mathrm{ml}\right)$ of $X$. campestris pv. phaseoli or X. campestris pv. phaseoli var. fuscans strains with the razor blade method. Rating scale: 1 = no visual symptoms or slight marginal necrosis; 2 = water-soaking, chlorosis, or necrosis (blight) in $<25 \%$ of the inoculated area; $3=25$ to $50 \%$ blight; and $4=>50 \%$ blight. Negative controls consisted of plants inoculated with distilled water and received rating of 1 . Numbers represent means of five replicates in each of three independent experiments. Coefficient of variation $(\%)=13.1, S_{\mathrm{y}}$ strains $=0.084, S_{\mathrm{y}}$ genotypes $=$ 0.133 , and $\mathrm{S}_{\mathrm{y}}$ strains $\times$ genotypes $=0.265$.

${ }^{y}$ Means followed by the same letter are not significantly $(P<0.05)$ different between bean cultivars by Duncan's multiple range test.

${ }^{\mathrm{z}}$ Means followed by the same letter are not significantly $(P<0.01)$ different between $X$. campestris pv. phaseoli and X. campestris pv. phaseoli var. fuscans strains by Duncan's multiple range test. 
known that the causal agent of $\mathrm{CBB}$ disease exists in two forms, yellow-pigmented $X$. campestris pv. phaseoli and the melanin-like (brown)-pigmented $X$. campestris pv. phaseoli var. fuscans. Furthermore, it has been established that these two forms are genetically distinct $(5,6,11,12,20)$, although the biological and taxonomic significance of this variability is not well understood. The development of molecular tools for genetic fingerprinting of bacteria (e.g., rep-PCR and RFLP analyses) has allowed for the examination of genetic diversity among $X$. campestris pathovars and strains within pathovars. These studies have revealed that pathovars of $X$. campestris are genetically distinct $(20,21)$, but that some pathovars are heterogeneous (i.e., composed of distinct genotypes). For example, X. campestris pv. vesicatoria is composed of two distinct types (43), whereas $X$. campestris pv. hederae is composed of a number of distinct genotypes $(25,44)$.

In this study, genetic fingerprinting tools were used to examine variability among common blight bacteria, and an attempt was made to correlate variability with biological properties (e.g., pathogenicity). Results of surveys conducted in Malawi and Tanzania revealed that both $X$. campestris pv. phaseoli and $X$. campestris pv. phaseoli var. fuscans were associated with CBB, but that $X$. campestris pv. phaseoli var. fuscans was more common in Tanzania. More extensive and systematic sampling could establish whether both $X$. campestris pv. phaseoli and X. campestris pv. phaseoli var. fuscans predominate in Malawi, whereas $X$. campestris pv. phaseoli var. fuscans predominates in Tanzania. Nonetheless, the results of these surveys are consistent with those of Opio et al. (27), who found X. campestris pv. phaseoli var. fuscans $(60 \%)$ and $X$. campestris pv. phaseoli $(40 \%)$ associated with $\mathrm{CBB}$ in East Africa (primarily Uganda). X. campestris pv. phaseoli var. fuscans also commonly is associated with common blight in South Africa (D. Fourie, personal communication). Thus, it is clear that $X$. campestris pv. phaseoli var. fuscans is a major causal agent of CBB in East Africa.

Genetic fingerprinting of $X$. campestris pv. phaseoli strains revealed three distinct genotypes, two of which were specific for strains from East Africa (e.g., Kenya, Malawi, Tanzania, and Uganda). The third genotype included strains from the New World (e.g., Brazil, Colombia, the Dominican Republic, Mexico, Puerto Rico, and the United States), a strain from Spain, and three strains from a single field in Tanzania (T8-2, T8-3, and T8-4) (Table 1). Irrespective of genotype or geographical origin, $X$. campestris pv. phaseoli strains predominantly were isolated from Andean beans. The association between $X$. campestris pv. phaseoli and Andean beans was demonstrated further by the finding that the two East African X. campestris pv. phaseoli genotypes (represented by strains M11 and M17) were significantly more pathogenic on Andean than Middle American beans. The fact that this differential pathogenicity was not observed for the three New World $X$. campestris pv. phaseoli strains examined (P1, CNF27, and ES5) revealed a biological difference between the genetically distinct East African and New World X. campestris pv. phaseoli genotypes. It will be important to confirm these findings with a larger number of $X$. campestris pv. phaseoli strains from East Africa and other locations.

The finding of differential pathogenicity for the East African $X$. campestris pv. phaseoli genotypes on the two common bean gene pools, although obtained with a relatively small number of strains, supports the hypothesis that these strains have adapted to be pathogenic on Andean beans. This hypothesis also is supported by the predominance of Andean beans in East Africa, ever since the introduction of the common bean $\approx 400$ years ago. The high level of pathogenicity of the New World $X$. campestris pv. phaseoli strains on Andean and Middle American beans likely reflects the cultivation of beans of both gene pools in many bean-growing regions of the New World and, thus, selection pressure to evolve pathogenicity on both types of beans.
The genetic diversity between East African X. campestris pv. phaseoli strains and those from other locations indicates geographical isolation of the East African $X$. campestris pv. phaseoli genotypes. These $X$. campestris pv. phaseoli genotypes may have evolved from a common ancestor, with the East African genotypes evolving independently on Andean beans after an initial introduction, possibly in association with seed. Alternatively, the East African $X$. campestris pv. phaseoli genotypes may represent indigenous xanthomonads that independently evolved to be pathogenic on Andean beans. The latter scenario may be favored by the finding of two distinct East African genotypes. The detection of $X$. campestris pv. phaseoli strains with fingerprints similar to those from New World locations from a single field in Tanzania probably reflects introduction of these strains with seed. It will be of interest to determine if these $X$. campestris pv. phaseoli strains become established in Tanzania and how well they compete with $X$. campestris pv. phaseoli var. fuscans.

Results of the surveys in Tanzania revealed that $X$. campestris pv. phaseoli var. fuscans strains were associated with Andean and Middle American beans. Consistent with this finding, X. campestris pv. phaseoli var. fuscans strains from East Africa, as well as those from the New World, were highly pathogenic on Andean and Middle American beans. Taken together with the finding of relatively little genetic diversity among the $X$. campestris pv. phaseoli var. fuscans strains examined in this study (i.e., no distinct East African $X$. campestris pv. phaseoli var. fuscans genotypes were identified), these results indicate that $X$. campestris $\mathrm{pv}$. phaseoli var. fuscans is more homogeneous than $X$. campestris $\mathrm{pv}$. phaseoli. It is possible that $X$. campestris pv. phaseoli var. fuscans was more recently introduced into East Africa, perhaps via seed of Middle American beans, and that the prevalence of X. campestris pv. phaseoli var. fuscans in Tanzania indicates displacement of East African X. campestris pv. phaseoli genotypes by the more pathogenic $X$. campestris pv. phaseoli var. fuscans.

Genetic diversity among $X$. campestris pathovars (20) and strains within pathovars $(4,6,12)$ can be revealed by RFLP analyses. The results of RFLP analysis of common blight bacteria with repetitive DNA probes generally supported results of rep-PCR analyses. First, $X$. campestris pv. phaseoli var. fuscans and $X$. campestris pv. phaseoli strains were readily distinguished by both the P2 and P7 probes, consistent with previous results $(11,12,20)$. Second, both the P2 and P7 probes readily differentiated the East African $X$. campestris pv. phaseoli genotypes from other (mostly New World) $X$. campestris pv. phaseoli strains, with considerably more hybridization (i.e., copies of the repetitive elements) detected in the New World genotype ( $>10$ hybridizing fragments) compared with East African genotypes (1 to 2 hybridizing fragments). Finally, the P7 probe also differentiated strains of the two East African X. campestris pv. phaseoli genotypes. The low copy number of these repetitive elements in the East African $X$. campestris pv. phaseoli genotypes provides additional evidence that these strains are genetically distinct from the New World $X$. campestris pv. phaseoli strains, and supports the concept of geographical isolation of the East African X. campestris pv. phaseoli genotypes. The difference in the copy number of these repetitive elements in these $X$. campestris pv. phaseoli genotypes may reflect different selection pressures on these bacteria. However, the significance of these elements, in terms of the biological properties of common blight bacteria, is not known. In contrast to rep-PCR results, the RFLP analysis revealed genetic diversity among $X$. campestris pv. phaseoli var. fuscans strains, indicating that $X$. campestris pv. phaseoli var. fuscans strains are not clonal.

Bean gene pool (host) and pathogen relationship. Genetic diversity in the common bean exists on a number of levels. The most significant level reflects the two major domestication sites of this crop: Mesoamerica or Middle America (e.g., Colombia, Mexico, and countries of Central America) and Andean South America (e.g., Peru, Bolivia, and northern Argentina). This led to 
the emergence of the two major common bean gene pools: Andean and Middle American (9). Andean and Middle American beans can be differentiated based upon morphological and molecular characteristics, as well as partial reproductive isolation $(8,9,41)$

It now has been established that genetic diversity within populations of certain fungal pathogens of common bean (e.g., Phaeoisariopsis griseola, causal agent of angular leafspot [15, 29]; Colletotrichum lindemuthianum, causal agent of anthracnose [3,39]; and Uromyces appendiculatus, causal agent of bean rust [36]) may parallel genetic diversity in the common bean host, particularly that between the two major common bean gene pools. In these cases, genetically distinct pathogen genotypes are associated with the two common bean gene pools and, in general, pathogen genotypes associated with a particular gene pool tend to be more pathogenic on beans of that gene pool than on beans of the other gene pool (i.e., isolates from Andean beans are more pathogenic on Andean than Middle American beans and vice versa). Conversely, resistance to a pathogen genotype may be found in germ plasm of the common bean gene pool that this genotype is not associated with (i.e., resistance to isolates from Andean beans may be found in Middle American germ plasm and vice versa). This has led to the concept that these pathogens have coevolved with the common bean host toward an increased level of pathogenicity. Thus, our results with the East African $X$. campestris pv. phaseoli genotypes provide an example of a prokaryote pathogen that has coevolved (coadapted) with the common bean host in a similar manner (Table 4).

Although our results indicate that Middle American beans have some resistance to CBB induced by East African $X$. campestris pv. phaseoli genotypes, they also support previous reports that high levels of $\mathrm{CBB}$ resistance are not found in common bean (42). Our results also demonstrate the importance of identifying the type or types of common blight bacteria prevalent in a region in order to select appropriate strains for breeding for resistance. In the case of East Africa, breeding programs should include $X$. campestris pv. phaseoli var. fuscans as well as New World $X$. campestris pv. phaseoli strains in order to assure identification and incorporation of resistance to the most pathogenic common blight bacteria found in that region. To this end, the VAX lines, which combine various sources of CBB resistance (42), showed high levels of resistance to New World $X$. campestris pv. phaseoli and East African X. campestris pv. phaseoli and X. campestris pv. phaseoli var. fuscans strains (unpublished data). Thus, these lines offer promising sources of resistance for $\mathrm{CBB}$ breeding programs in East Africa and other regions.

\section{ACKNOWLEDGMENTS}

This research was supported by the USAID Bean/Cowpea Collaborative Research Support Program (CRSP). We thank J. K. O. Ampofo, J. Bokosi, C. Miles, J. Myers, and S. Nchimbi-Msolla for assistance in collecting common blight samples that were used in this study; $\mathrm{M}$. Mercedes Otoya for providing total genomic DNA of $X$. campestris pv. phaseoli and $X$. campestris pv. phaseoli var. fuscans strains; R. L. Perez for assistance in the rep-PCR analyses; and M. Rojas for assistance in preparation of the figures.

\section{LITERATURE CITED}

1. Allen, D. J., Ampofo, J. K. O., and Wortman, C. S. 1996. Pests, diseases and nutritional disorders of the common bean in Africa: A field guide. CIAT Publication No. 260, Cali, Colombia.

2. Audy, P., Laroche, A., Saindon, G., Huang, H. C., and Gilbertson, R. L. 1994. Detection of the bean common blight bacteria, Xanthomonas campestris pv. phaseoli and X.c. pv. phaseoli fuscans, using the polymerase chain reaction. Phytopathology 84:1185-1192.

3. Balardin, R. S., and Kelly, J. D. 1998. Interaction between Colletotrichum lindemuthianum races and gene pool diversity in Phaseolus vulgaris. J. Am. Soc. Hortic. Sci. 123:1038-1047.
4. Barak, J. D., and Gilbertson, R. L. 2003. Genetic diversity of Xanthomonas campestris pv. vitians, the causal agent of bacterial leafspot of lettuce. Phytopathology 93:596-603.

5. Birch, P. R. J., Hyman, L. J., Taylor, R., Opio, A. F., Bragard, C., and Toth, I. K. 1997. RAPD PCR-based differentiation of Xanthomonas campestris pv. phaseoli and Xanthomonas campestris pv. phaseoli var. fuscans. Eur. J. Plant Pathol. 103:809-814.

6. Chan, J. W. Y. F., and Goodwin, P. H. 1999. Differentiation of Xanthomonas campestris pv. phaseoli var. fuscans by PFGE and RFLP. Eur. J. Plant Pathol. 105:867-878.

7. Dellaporta, S. L., Wood, J., and Hicks, J. B. 1983. A plant DNA minipreparation: Version II. Plant Mol. Biol. Rep. 1:19-21.

8. Gepts, P. 1998. Origin and evolution of common bean: Past events and recent trends. HortScience 33:1124-1130.

9. Gepts, P., Osborn, T. C., Rashke, K., and Bliss, F. A. 1986. Phaseolinprotein variability in wild forms and landraces of the common bean (Phaseolus vulgaris): Evidence of multiple centers of domestication. Econ. Bot. 40:451-468.

10. Gilbertson, R. L., and Maxwell, D. P. 1992. Common blight of bean. Pages 18-39 in: Diseases of International Importance. Vol 2. H. S. Chaube, U. S. Singh, and A. N. Mukhopadhay, eds. Prentice Hall, Inglewood Cliffs, NJ.

11. Gilbertson, R. L., Maxwell, D. P., Hagedorn, D. J., and Leong, S. A. 1989. Development and application of a plasmid DNA probe for detection of bacteria causing common bacterial blight of bean. Phytopathology 79:518-525.

12. Gilbertson, R. L., Otoya, M. M., Pastor-Corrales, M. A., and Maxwell, D. P. 1991. Genetic diversity in common blight bacteria is revealed by clonal repetitive DNA sequences. Ann. Rep. Bean Improv. Coop. 34:37-38.

13. Gilbertson, R. L., Rand, R. E., and Hagedorn, D. J. 1990. Survival of Xanthomonas campestris pv. phaseoli and pectolytic strains of $X$. campestris in bean debris. Plant Dis. 74:322-327.

14. Goodwin, P. H., and Sopher, C. R. 1994. Brown pigmentation of Xanthomonas campestris pv. phaseoli associated with homogentistic acid. Can. J. Microbiol. 40:28-34.

15. Guzmán, P., Gilbertson, R. L., Nodari, R., Johnson, W. C., Temple, S. R., Mandala, D., Mkandawire, A. B. C., and Gepts, P. 1995. Characterization of variability in the fungus Phaeoisariopsis griseola suggests coevolution with the common bean (Phaseolus vulgaris). Phytopathology 85:600-607.

16. Hildebrand, D. C., Palleroni, N. J., and Schroth, M. N. 1990. Deoxyribonucleic acid relatedness of 24 xanthomonad strains representing 23 Xanthomonas campestris pathovars and Xanthomonas fragariae. J. Appl. Bacteriol. 68:263-269.

17. Johnson, W., and Gepts, P. 2002. The role of epistasis in controlling seed yield and other agronomic traits in Andean $\times$ Mesoamerican cross of common bean (Phaseolus vulgaris L.). Euphytica 125:69-79.

18. Kado, C. I., and Heskett, M. G. 1970. Selective media for isolation of Agrobacterium, Corynebacterium, Erwinia, Pseudomonas, and Xanthomonas. Phytopathology 60:969-976.

19. Koike, S. T., Barak, J. D., Henderson, D. M., and Gilbertson, R. L. 1999. Bacterial blight of leek: A new disease in California caused by Pseudomonas syringae. Plant Dis. 83:165-170.

20. Lazo, G. R., Robin, R., and Gabriel, D. W. 1987. Pathovars of Xanthomonas campestris are distinguishable by restriction fragment-length polymorphism. Int. J. Syst. Bacteriol. 37:214-221.

21. Louws, F. J., Fulbright, D. W., Stephens, C. T., and de Bruijn, F. J. 1994. Specific genomic fingerprinting of phytopathogenic Xanthomonas and Pseudomonas pathovars and strains generated with repetitive sequences and PCR. Appl. Environ. Microbiol. 60:2286-2295.

22. Melis, R. J. M. 1987. Disease and pest problems of beans (Phaseolus vulgaris) in South Africa. Occasional Publication No. 7. University of Natal, Pietermaritzburg, South Africa.

23. Mkandawire, A. B. C., and Gilbertson, R. L. 2001. Attempts to eradicate Xanthomonas campestris pv. phaseoli from bean seed using surface disinfection. Annu. Rep. Bean Improv. Coop. 44:135-136.

24. Msuku, W. A. B., Saka, V. W., and Munthali, D. C. 2000. Major diseases and insect pests of beans (Phaseolus vulgaris) in Malawi: Problems and their control. University of Malawi, Lilongwe, Malawi.

25. Norman, D. J., Chase, A. R., Stall, R. E., and Jones, J. B. 1999. Heterogeneity of Xanthomonas campestris pv. hederae strains from araliaceous hosts. Phytopathology 89:646-652.

26. Opio, A. F., Allen, D. J., and Teri, J. M. 1995. The role of weeds and nonhost crops in the survival of Xanthomonas campestris pv. phaseoli in Uganda. Annu. Rep. Bean Improv. Coop. 38:166-167.

27. Opio, A. F., Allen, D. J., and Teri, J. M. 1996. Pathogen variation in Xanthomonas campestris pv. phaseoli, the causal agent of common bacterial blight in Phaseolus beans. Plant Pathol. 45:1126-1133.

28. Pastor-Corrales, M. A., Beebe, S., and Correa, F. J. 1981. Comparing 2 inoculation techniques for evaluating resistance in beans to Xanthomonas campestris pv. phaseoli. Pages 493-503 in: Proc. Fifth Int. Conf. Plant Pathogenic Bacteria. C. J. Lozano, ed. CIAT, Cali, Colombia. 
29. Pastor-Corrales, M. A., and Jara, C. 1995. La evolucion de Phaeoisariopsis griseola con el frijol comun en America latina. Fitopatol. Colomb. 19:15-24.

30. Rademaker, J. L. W., and de Bruijn, F. J. 1997. Characterization and classification of microbes by rep-PCR genomic fingerprinting and computer assisted pattern analysis. Pages 151-171 in: DNA Markers: Protocols, Applications and Overviews. G. Cactano-Anolles and P. M. Gresshoff, eds. John Wiley \& Sons, New York.

31. Restrepo, S., Velez, C. M., and Verdier, V. 2000. Measuring the genetic diversity of Xanthomonas axonopodis pv. manihotis within different fields in Colombia. Phytopathology 90:683-690.

32. Saettler, A. W. 1989. Common bacterial blight. Pages 261-283 in: Bean Production Problems in the Tropics. H. F. Schwartz and M. A. PastorCorrales, eds. Centro Internacional de Agricultura Tropical, Cali, Colombia.

33. Saettler, A. W., Cafati, C. R., and Weller, D. M. 1986. Nonoverwintering of Xanthomonas bean blight bacteria in Michigan. Plant Dis. 70:285-287.

34. Sahin, F., Abbasi, P. A., Lewis Ivey, M. L., Zhang, J., and Miller, S. A. 2003. Diversity among strains of Xanthomonas campestris pv. vitians from lettuce. Phytopathology 93:64-70.

35. Sambrook, J., Fritsch, E. F., and Maniatis, T. 1989. Molecular Cloning: A Laboratory Manual. 2nd ed. Cold Spring Harbor Laboratory, Cold Spring Harbor, NY.

36. Sandlin, C. M., Steadman, J. R., and Araya, C. M. 1999. Isolates of Uromyces appendiculatus with specific virulence to landraces of Phaseolus vulgaris of Andean origin. Plant Dis. 83:108-113.

37. Schuster, M. L., Coyne, D. P., and Hoff, B. 1973. Comparative virulence of Xanthomonas phaseoli strains from Uganda, Colombia and Nebraska. Plant Dis. Rep. 57:74-75.

38. Scortichini, M., Marchesi, U., Rossi, M. P., Angelucci, L., and Dettori, M. T. 2000. Rapid identification of Pseudomonas avellanae field isolates, causing hazelnut decline in central Italy, by repetitive PCR genomic fingerprinting. J. Phytopathol. 148:153-159.
39. Sicard, D., Michalakis, Y., Dron, M., and Neema, C. 1997. Genetic diversity and pathogenic variation of Colletotrichum lindemuthianum in the three centers of diversity of its host, Phaseolus vulgaris. Phytopathology 87:807-813.

40. Silhavy, T. J., Berman, M. L., and Enquist, L. W. 1984. Experiments with Gene Fusions. Cold Spring Harbor Laboratory, Cold Spring Harbor, NY.

41. Singh, S. P., Gepts, P., and Debouck, D. G. 1991. Races of common bean (Phaseolus vulgaris L., Fabaceae). Econ. Bot. 45:374-396.

42. Singh, S. P., and Muños, C. G. 1999. Resistance to common bacterial blight among Phaseolus species and common bean improvement. Crop Sci. 39:80-89.

43. Stall, R. E., Beaulieu, C., Egel, D., Hodge, N. C., Leite, R. P., Minsavage, G. V., Bouzar, H., Jones, J. B., Alvarez, A. M., and Benedict, A. A. 1994. Two genetically diverse groups of strains are included in $X$. campestris pv. vesicatoria. Int. J. Syst. Bacteriol. 44:47-53.

44. Sulzinski, M. A. 2001. Differentiation of Xanthomonas campestris pvs. pelargonii and hederae by polymerase chain reaction. J. Phytopathol. 149:45-49.

45. Valladares-Sanchez, N. E., Coyne, D. P., and Schuster, M. L. 1979. Differential reaction of leaves and pods of Phaseolus germplasm to strains of Xanthomonas phaseoli and transgressive segregation for tolerance from crosses of susceptible germplasm. J. Am. Soc. Hortic. Sci. 104:648-654.

46. Vauterin, L., Rademaker, J., and Swings, J. 2000. Synopsis on the taxonomy of the genus Xanthomonas. Phytopathology 90:677-682.

47. Versalovic, J., Koeth, T., and Lupiski, J. R. 1991. Distribution of repetitive bacterial genomes. Nucleic Acids Res. 19:6823-6831.

48. Weingart, H., and Volksch, B. 1997. Genetic fingerprinting of Pseudomonas syringae pathovars using ERIC-, REP-, and IS50-PCR. J. Phytopathol. 145:339-345.

49. Zapata, M. 1990. Host-pathogen interaction of the tepary bean Phaseolus acutifolius, with the common bean blight pathogen, Xanthomonas campestris pv. phaseoli. Diss. Abstr. Int. 50:3791B. 